\title{
DESIGN FUTURES - A SYMPOSIUM THAT CONNECTED GRADUATES AND ALUMNI AROUND THE FUTURE OFWORK
}

\author{
Caro McCaw, Megan Brasell-Jones, \\ Angela Lyon and Denise Narciso
}

\begin{abstract}
At the end of a year full of Covid-fuelled change and upheaval, a team of Communication Design staff presented an inaugural symposium aimed at graduating students. The one-day event - "Design Futures" - assembled and presented a variety of professional design approaches to practices experienced by our alumni - students who have completed our programme and are now working in the industry.
\end{abstract}

Times have never been bleaker for our graduating communication designers. Unofficial attempts at monitoring graduate employment outcomes lead us to believe that over the past 12 years most of our graduates (over 80 percent) have found design-related work within 18 months of graduation. More formal surveys produced by Otago Polytechnic support these figures. However, in 2020 we acknowledged that the Covid-19 pandemic had reduced opportunities for travel, and had created an employment-averse industry.

With this problem at the forefront of our symposium plans, we drew on those design alumni with whom we have maintained regular contact. These are designers we frequently ask to support us with their current industry knowledge, and in peer review activities such as acting as external examiners or moderators and external industry advisors. In this community we receive critique and feedback, and a high degree of trust and understanding has developed, allowing our programme to continually develop and respond to changing industry trends and needs.

Design Futures took place over six hours, on 19 November 2020, the day of our end-of-year graduate exhibition opening (see https://showcase.op.ac.nz/november-16/debrief/). Our first Design Futures symposium gathered graduates and alumni for a day of presentations, panels and lightning portfolio presentations. Event branding and collateral were developed by a senior graduating student, MaxThompson. A number of student volunteers helped Max with the event production, including managing registration and event signage, audio and photographic recording of the event and ushering speakers and attendees.

Max had taken a retrospective design theme for his brand language, looking back to the technology of the past to help us see how far we have come. He employed Mac desktop icons from the 1990s, when computers first became used by designers, and included some iconic and familiar pixel art images. His use of two-colour ink and Risographic printing for the event programmes refer to techniques from another era and provoked us to consider what the upcoming era may hold. The red-and-black branding was used for the event programme, wayfinding, t-shirts for event volunteers and on-screen titles. Perhaps the most poignant reference in Max's branded work was the use of floppy disks as symposium lanyards, collected from a local e-waste facility. What, might we consider - in these rapidly changing conditions - were we leaving behind for others to reuse, or find as detritus of our time? 


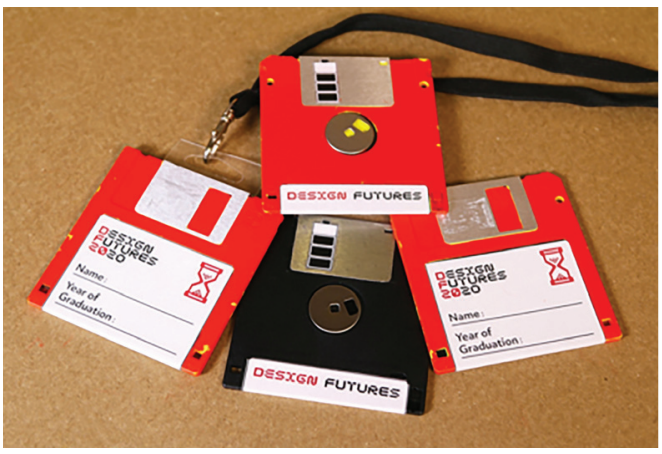

Figure I. Design Futures lanyards, made from floppy disks sourced through local e-waste collectors.

Design by MaxThompson, 2020.

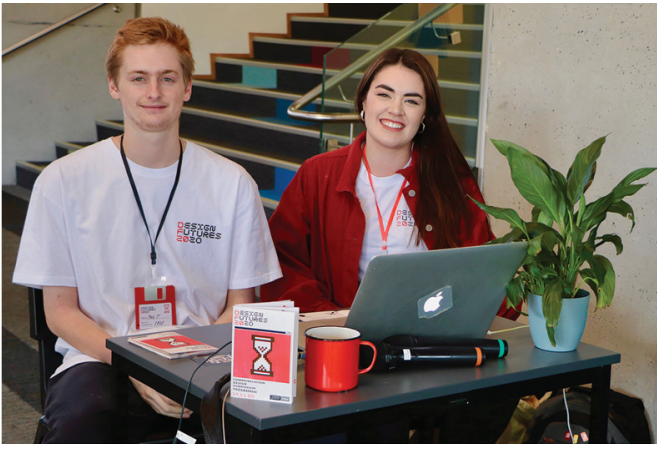

Figure 2. MaxThompson and Tiahli Curran-Hogg welcome symposium attendees. Photograph: Angela Lyon, 2020.

The event programme included a keynote by Noel Brown, outgoing CE of Wellington-based design company DNA and active in the Design for Social Innovation network, two panel presentations and lightning portfolio meetings, where outgoing students could get portfolio advice from experienced designers. An afternoon open-floor conversation focused on how design education could better meet the needs of our graduates, and touched on both understanding work environments (including setting up as contractors in a job shortage context) and ways that graduates could access some of the people and equipment that they later realised they had taken for granted as students. The symposium also included an exhibition, where all presenters were invited to exhibit recent work.
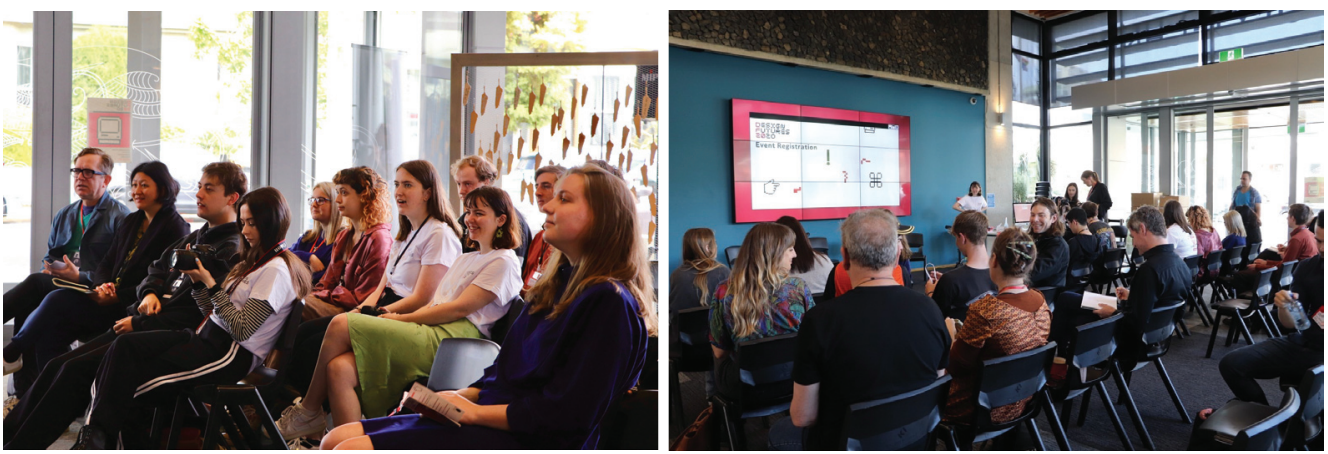

Figure 3.The morning of the Design Futures symposium, an audience gathers. The Hub, Otago Polytechnic. Photograph: Angela Lyon, 2020

In this paper we focus on the diversity of opinions and experiences expressed in our first panel, "Diverse Practices," with designers Vincent Egan, Lynda Henderson and Craig Scott.

Their stories map three different directions that design education is leading our graduates and partners. Lynda Henderson has adopted a user-centred approach to creative problem finding (and solving) using design thinking. Lynda's role as "mission commander" at Dunedin design agency Firebrand has seen the company diversify from a traditional web and print design focus to social innovation, marketing and business transformation (https://firebrand. $\mathrm{nz} /$ portfolio/). A recent example of this approach is the Youth Employment Success digital platform developed for the Ministry of Social Development to connect unemployed youth with local businesses for experience and employment opportunities. 
Craig Scott's practice is found in a combination of roles, from his job at Otago Museum (head of Exhibitions and Creative Services) to his engagement in several Dunedin not-for-profit creative organisations outside of his job. Craig runs the Design Kids Dunedin chapter (https:/thedesignkids.org/tdktuesdays/) and is chair of Dunedin Designed Inc, who run the Guild design store (www.guilddunedin.co.nz/). Craig is also a steering group member of Dunedin Dream Brokerage (www.dunedindreambrokerage.nz/) and runs his own business, Self-Destruct Studio (https://selfdestructstudio.com/).

Vincent Egan works in kaupapa Māori contexts in the emerging "taniwha economy." The taniwha economy is a term first used by then Mãori Affairs Minister Hon Dr Pita Sharples, in relation to the Chinese "dragon economy" cited in Kōkiri 27 - Powering the Taniwha Economy, Kōanga - Spring 2012. His co-owned business, Māui Studios, combines a mix of web, film, animation, print and graphic, and more recently mixed reality storytelling projects for clients. They create their own narratives and graphic novels, and engage with blue-sky initiatives including Vincent's Masters project, Mythic Tāne, VR contemporary storytelling of traditional pūrākau. Māui Studios are "passionate about creating meaningful content in the te Ao Māori digital space" (www.māuistudios.co.nz/about/).

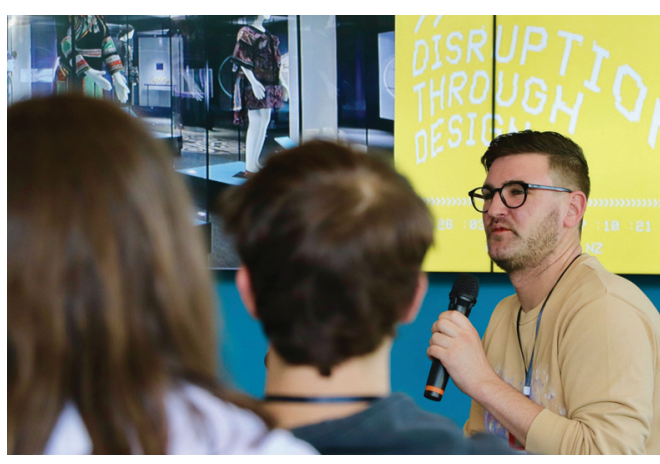

Figure 4. Craig Scott.

Photograph: Angela Lyon, 2020.

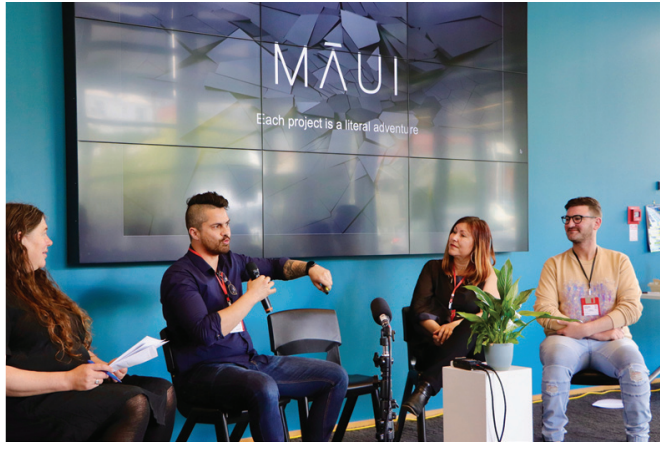

Figure 5.Vincent Egan from Māui Studios, presents. Photograph: Angela Lyon, 2020.

After each presenter had showed examples of their work, the panel considered ways in which design education may need to adapt to meet the diverse needs of our learners - from the three different designers' perspectives. We considered ideas relating to both design work and the value of design in these changing times.

We asked three questions:

I. How is Covid-19 effecting your work practices, both during lockdown 2020 and in the future?

2. One of Otago Polytechnic's values is "Our people make a better world." How do you think your design practice/s contribute to designing positive futures?

3. What is your advice to learners and teachers of design, so that we may support these positive futures?

Three themes emerged from the panel, containing some useful advice for fresh graduates.

With regard to Covid, all three designers acknowledged big shifts in the way that they worked and where they worked. Along with the inability to complete work that required face-to-face connection, both the types of work (for example, film work on location) and personal connections with clients suffered. For Otago Museum this meant a major loss of income, particularly through the café and shop during lockdown and the museum's closure.

Consequently, the designers' business focus had to shift in response, but there were silver linings. Vincent described this as a time to look inward, both looking after each other and having time for personal upskilling. While Lynda 
acknowledged that a number of projects were necessarily "put on hold," Firebrand's focus on digital services and products became highly valued and the company had had a busy year. For some of the developers at Firebrand, working from home has become preferred, with some of their team now only coming into the office for meetings. Otago Museum postponed the opening dates of upcoming exhibitions and, as a result, Craig found time to develop additional exhibition materials, such as video clips and a catalogue essay. While Guild design store saw a loss of tourists, the rise of the supportive Buy Local movement helped the store stay afloat.

\section{Our second question related to social drivers and} how the panel members considered their design practice/s in relation to and as contributing to, designing positive futures.

All three panellists felt strongly about their workplace having a positive social focus. ForVincent, Māui Studios is inherently about empowering young people. As emerging designers, they have received help and guidance from people with more experience and they see their role now as "opening doors for others." Together, they are constantly "keeping an eye on emerging technologies" to be sure they can positively enable their clients, and young people, in this fastchanging world. Māui Studios' focus at this time was on developing skills and services in virtual production.

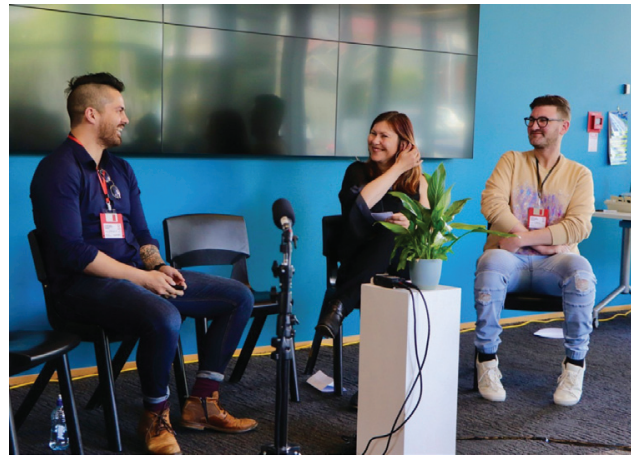

Figure 6. The "Diverse Practices" Panel:

Vincent Egan, Lynda Thompson and Craig Scott.

Photograph: Angela Lyon, 2020. This emerging method in filmmaking uses software to combine live-action footage and computer graphics in real time. Filmmakers and animators work together in a digital space across multiple locations, where digital and physical environments merge on set.

Lynda considered Firebrand's focus on social responsibility and the power of design to "influence people in a positive way." She reflected on the YES (Youth Employment Service) and how their digital services have helped to connect young people with employment experiences around the country. Lynda commented on the changing nature of work, noting that in these times of intense digital - and at times remote - work, more effort was focussed on maintaining good relationships. There was a growing recognition of social responsibility and the need to give back, starting with local communities and businesses.

Craig identified the emerging role of museums to become a "safe space for unsafe conversations." He suggested that we could expect the emergence of "ideas not normally seen in museums ... provocative experiences where people can make up their own mind rather than being told what to think." This trend could be considered a democratisation of museums, with a shift in focus from objects to people. In Craig's vision of a better world, designers will support a broad consultative process where people assemble to learn from each other in the context of museum collections, rather than didactically from experts who educate visitors. In this social space the museum has a role to play in supporting collaborative practices where we can all learn from each other, both through successes and mistakes.

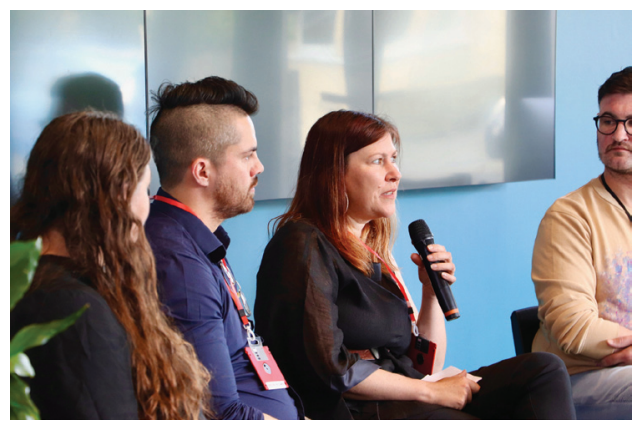

Figure 7. (Left to right) Caro McCaw (panel chair), Vincent Egan (Maui Studios), Lynda Henderson (Firebrand) and Craig Scott (Otago Museum). Photograph: Angela Lyon, 2020. 
Our third question focused on advice for learners and teachers. In line with much of the discourse around Covid-19, the designers all stressed the importance of a personal focus on wellbeing and making a very real effort to maintain a balance between work commitments and other parts of a person's life. We are all balancing busy lives, and the design industry is a high-pressure one that constantly changes.

Vinnie was candid about the initial freefall and "chaos" he experienced. His heart-felt counsel included a reminder to "surround yourself with the right people," folk who are both "supportive" but who can also inject a "dose of reality" when required. He offered concrete advice about learning to be more efficient, such as itemising each day and keeping to time slots. Short- and medium-term plans and goals help to maintain a hierarchy of tasks, and keep people from getting distracted from what is most important.

He also highlighted the importance of actively seeking projects that align with one's own values - "energising projects" - as they help to keep up momentum and positive energy.

This sentiment was echoed by Lynda who - also aware of unrealistic personal expectations by young designers - reiterated the importance of "being honest about time." Designers are eternal optimists and can promise too much. This can easily lead to losing out on sleep, and twice Lynda has had to take time out of work to reassess and avoid burnout. "Seeking balance can be hard when you work in a rewarding industry, but you need to find a balance between what you spend your time doing and what fills your cup." She also reflected on the benefits of individuals watching out for each other - to champion others, but also to speak up when behaviour is amiss.

Craig talked of music as his space of relaxation, away from work; he also often engages in his own creative projects to feel connected.

As well as giving practical advice to emerging designers entering the industry, there was also a challenge issued - Lynda prompted designers to diversify and consciously choreograph networks to their own advantage. She reminded us that it's "all about connections." And, as well as "keeping a finger on the pulse," Vinnie urged attendees to develop "PhD-level thinking" by taking the time to be aware of design experts and visionaries - to immerse ourselves in creative culture at the highest levels, which will then inform our own work.

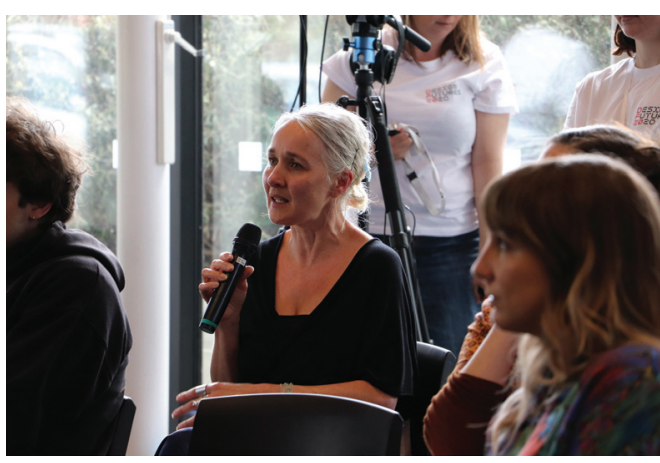

Figure 8. Audience member Inge Andrew asks the panel a question. Photograph: Angela Lyon, 2020.

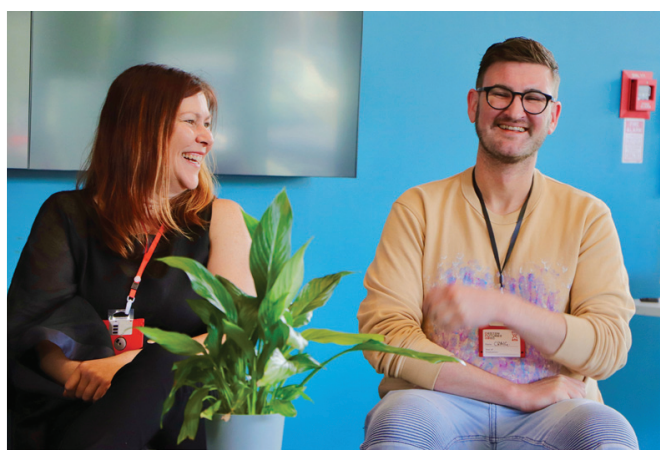

Figure 9. Lynda Thompson and Craig Scott. Photograph: Angela Lyon, 2020.

As parting advice, Craig and Lynda encouraged graduates to "ask questions, be brave and talk to others." This set the tone for the rest of the day, with students and graduates seeking advice from those more experienced than themselves about their next steps. As those present acknowledged, the future has never been more uncertain, and this is not just true for designers. 
As teachers, this was our first effort to open professional conversations about design education and the world of work to students and alumni, beyond the formal external advisory events we negotiate as part of regular programme delivery. The symposium was enthusiastically received by our senior students and graduates, with helpful professional advice going beyond pointers as to 'how to make it as a designer.' Without doubt, design is a valuable and valued profession, as designers contribute to so many aspects of our personal and professional lives. However, in the symposium agility and connectedness emerged as common themes, along with a strong focus on personal time management and wellbeing, where work is not a designer's sole activity. The symposium's visual identity was also reflected in the panel discussion; the use of very old media only reinforced our industry's rapid pace of change and the need to constantly consider the forces of change at work, both digital and social.

This event and our subsequent reflections may be considered a mark in the sand, as we examined the design profession through the lens of some of our graduates in senior design positions, in this moment. We plan to organise new events and wonder - what will the future bring?

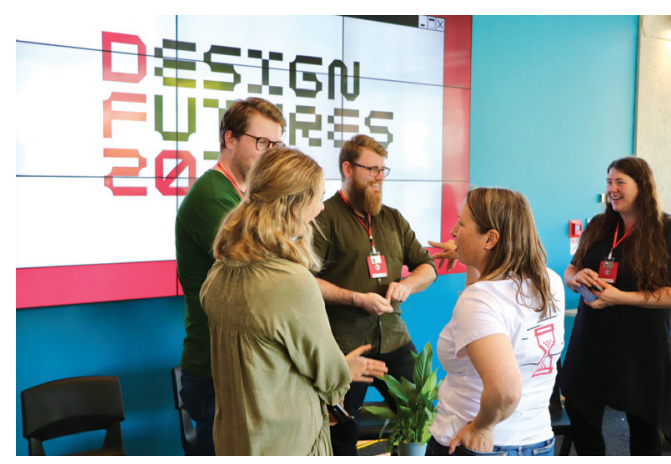

Figure 10. Attendees, alumni and organisers chat. Photograph: Katie Merrillees, 2020.

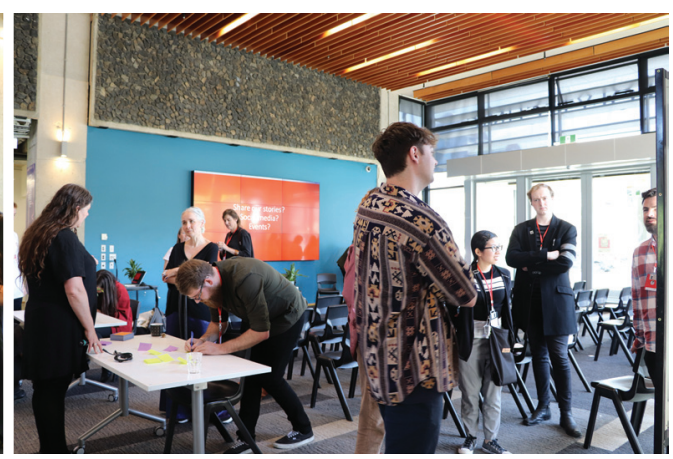

Figure II. Alumni feedback session after the symposium. Photograph: Katie Merrillees, 2020.

Dr Caro McCaw (ORCID ID: https://orcid.org/0000-0002-6775-7409) investigates how we come to understand our landscapes, local knowledge, and regional cultures and contexts through collaborative creative practice. She asks how we may work around colonial ways of seeing to visualize and understand our shared histories and sites more socially. Caro is an Associate Professor and Academic Leader in Communication Design at Otago Polytechnic. She is involved in a wide range of local community and regional development projects often working with collaborative student-staff teams, and local community groups, including museums.

Meg Brasell-Jones (ORCID ID: https://orcid.org/0000-000I-8065-3527) is a senior visual communication lecturer at Te Maru Pūmanawa/College of Creative Practice and Enterprise at Otago Polytechnic/Te Kura Matatini ki Otago. Through practice and research, she blends her interests in education, design, biculturalism, and ecology to contribute to a more sustainable future.

Angela Lyon is a lecturer in Communication Design who teaches visual communication and photography. Angela graduated from Dunedin School of Art, Otago Polytechnic, with a Masters of Fine Arts in 2007.

Denise Narciso is a Lecturer at Te Maru Pūmanawa, College of Creative Practice and Enterprise. She holds a Bachelor's degree in Advertising Management and finished her Postgraduate Diploma in Design at OP. Denise has a passion for teaching graphic design, branding, advertising, and social media. Her research interest areas include developing a Project-Based Learning framework for the degree, enhancing learner experiences, and strengthening partnership internally within $\mathrm{OP}$ and external community partners. Denise also manages all the enquiries for projects and evaluates their suitability for student involvement. 